\title{
Pelatihan dan Pendampingan Kepada Pelaku UMKM di Perumahan Buana Impian 2 Kota Batam
}

\author{
Sunarto Wage $\left.{ }^{1 *}\right)$ \\ ${ }^{1}$ Prodi Akuntansi Universitas Putera Batam
}

Informasi Artikel

Diterima Redaksi : 22 September 2020

Revisi Akhir : 22 Oktober 2020

Diterbitkan Online: 26 Oktober 2020

Kata Kunci : UMKM

\begin{abstract}
Abstrak Kegiatan pengabdian kepada masyarakat ini mengambil lokasi di Perumahan Buana Impian 2 RW 028 Kelurahan Tembesi, Kecamatan Sagulung, Kota Batam. Di perumahan Buana Impian 2 ada 4 Rukun Tetangga (RT) dengan kepala rumah rangga sebanyak 827 KK. Pelatihan dan pendampingan sangat penting kepada pelaku UMKM tentang manajemen keuangan dan manajemen pemasaran. Tujuan utama dilakukan Pengabdian Kepada Masyarakat (PKM) ini adalah untuk pengembangan Usaha Mikro Kecil Menengah (UMKM) di Perumahan Buana Impian 2, ada sekitar 35 UMKM di perumahan Buana Impian 2 dengan berbagai jenis kegiatan seperti ; kuliner, jualan kebutuhan harian, usaha air isi ulang, pangkas rambut, penjahit dan lainlain. Pelatihan dan pendampingan yang diberikan kepada peserta dalam bentuk ceramah dan diskusi membahas permalahan permasalahan yang dihadapi UMKM di Perumahan Buana Impian 2. Materi pelatihan dan pendampingan kepada pelaku UMKM tentang manajemen usaha dan kewirausaha, pelatihan mengenai pembukuan pemasukan dan pengeluaran, bagaimana mempromosikan usaha serta akses-akses permodalan yang bisa ditempuh oleh pelaku UMKM. Setelah mengikuti pelatihan dan pendampingan pelaku UMKM diharapakan usahanya semakin maju dan berkembang dengan baik.

Kata kunci: Pelatihan, pendampingan, UMKM
\end{abstract}

\section{PENDAHULUAN}

Pelatihan dan pendampingan kepada pelaku Usaha Mikro Kecil dan Menengah (UMKM) akan dapat memotivasi pelaku UMKM yang bergerak di sektor usaha rumahan akan semakin bersemangat dan berharap kedepan akan mampu berdaya saing dengan usaha lainnya. Banyak pelaku UMKM belum mendapatkan sentuhan pelatihan dan pendampingan dalam menjalankan usahanya. Padahal, pelatihan dan pendampingan usaha sangatlah diharapkan. Masih banyak pelaku UMKM belum bisa mengelola keuangan usaha secara maksimal. Kebanyakan pelaku usaha UMKM hanya fokus melakukan produksi dan menjual barang, setelah itu tidak dicatat keuangan yang masuk.. Pencatatan keuangan usaha memang masih kurang dianggap penting dilakukan sejumlah pelaku UMKM. Padahal dengan adanya pencatatan, pelaku UMKM akan bisa mengetahui perkembangan usaha yang dijalankan.
Persoalan pemasaran dan promosi masih menjadi salah satu kendala terbesar bagi pelaku usaha mikro, kecil dan menengah dalam meningkatkan skala bisnisnya di Indonesia pada umumnya dan khusunya pelaku UMKM di Perumahan Buana Impian 2. Para pelaku UMKM sering mengalami kendala dalam menjual produknya dikarenakan dari kecenderungan para pelaku usaha tersebut yang lebih memfokuskan diri dalam proses produksi tanpa diimbangi oleh pemasaran dan promosi. Pelatihan dan pendampingan pemasaran dan manajemen keuangan sangat dibutuhkan bagi pelaku UMKM. Sebagai informasi UMKM memiliki kontribusi sebesar $60,3 \%$ dari total produk domestik bruto (PDB) di Indonesia. Selain itu, UMKM menyerap $97 \%$ dari total tenaga kerja dan $99 \%$ dari total lapangan kerja. Pada 2018, UMKM tercatat sebanyak 64,2 juta unit.

Usaha Mikro Kecil dan Menengah adalah usaha produktif yang dimiliki 
perorangan maupun badan usaha yang telah memenuhi kriteria sebagai usaha mikro sesuai dengan undang-undang No. 20 tahun 2008. Kriteria dari UMKM yang ada di Indonesia menurut Undang-Undang N0. 20 Tahun 2008.

1. Usaha mikro. Usaha mikro yang dapat diartikan sebagai suatu usaha ekonomi yang produktif dimiliki individu atau badan usaha yang tentunya memenuhi ciri-ciri sebagai usaha mikro. Hasil dari penjualan usaha mikro minimal $\mathrm{Rp}$. 300.000.000,- dalam jangka satu tahun.

2. Usaha kecil. Usaha kecil, yang biasa diartikan sebagai suatu usaha ekonomi yang produktif dan berdiri sendiri atau independen dan dimiliki oleh suatu kelompok atau perorangan badan usaha dan bukan cabang dari usaha utama. Suatu usaha dikatakan usaha kecil apabila usaha tersebut memiliki kekayaan yang bersih mencapai Rp 50.000.000,- dengan kebutuhan yang dipakai maksimal $\mathrm{Rp}$ $500.000 .000,-$.

3. Usaha menengah. Usaha menengah merupakan suatu usaha dalam ekonomi yang produktif dan bukan cabang dari usaha utama atau perusahaan pusat serta menjadi bagian secara tidak langsung maupun secara langsung bagi usaha kecil dan atau usaha besar. Kekayaan dari usaha menengah mencapai Rp 500.000.000,sampai Rp 10.000.000.000,-

Berdasarkan kriteria di atas maka sebagian besar UMKM di Perumahan Buana Impian 2 termasuk usaha mikro dan kecil sehingga sangat membutuhkan perhatian dan bantuan dari berbagai pihak agar bisa cepat berkembang.

\section{METODE}

Solusi untuk mengatasi permasalahan yang menjadi prioritas adalah: (1) Permasalahan pemasaran, (2) Permasalahan manajemen usaha dan administrasi. Pelaksanaan pelatihan dan pendampingan pelaku UMKM dilaksanakan dengan beberapa tahapan diantaranya :

1. Survey di lokasi UMKM, kegiatan survey dilakukan untuk mengetahui kondisi riil mitra UMKM di Perumahan Buana Impian 2.

2. Memberikan materi atau ceramah kepada pelatihan kepada tentang manajemen usaha dan kewirausaha, pelatihan mengenai pembukuan pemasukan dan pengeluaran, bagaimana mempromosikan usaha serta akses-akses permodalan yang bisa ditempuh oleh pelaku UMKM.

3. Melakukan pendampingan kepada UMKM. Pada kegiatan ini, tim pengabdian berperan sebagai pendamping yang memberikan arahan dan bimbingan secara tekni kepada peserta pelatihan dan pendampingan kepada pelaku UMKM. Kegiatan pendampingan pada UMKM di Perumahan Buana Impian 2 dilakukan sebanyak 3 (tiga) kali. Kegiatan pendampingan berfokus pada tercapainya tujuan pelaksanaan pengabdian kepada masyarakat. Selain itu dalam kegiatan pendampingan juga dilakukan praktek penyusunan laporan keuangan serta optimaliasasi media pemasaran berbasis online.

\section{HASIL DAN PEMBAHASAN}

Peserta pelatihan dan pendampingan pelaku UMKM di Perumahan Buana Impian 2 berjalan lancar dan peserta mengikuti kegiatan dengan seksama dan terjadi diskusi untuk memecahkan permasalahan yang mereka hadapi sehari hari untuk mengembangkan usahanya kearah lebih baik. Materi pelatihan ini diberikan sesuai dengan bidang usahanya, pada umumnya para peserta usahanya di bidang jasa dan perdagangan. Pelatihan yang diberikan terutama tentang manajemen pemasaran dan manajemen keuangan.

1. Pelatihan dan pendampingan manajemen keuangan. Materi yang sampaikan kepada peserta meliputi; membuat pembukuan, membuat neraca, membuat laporan labar rugi, membuat laporan arus kas, dan perubahan modal.

2. Pelatihan dan pendampingan manajemen pemasaran. Pelatihan dan pendampingan manajemen pemasaran dilaksanakan agar pelaku UMKM untuk mengetahui dan memahami cara dan strategi pemasaran modern dengan memanfaatkan teknologi informasi. Melaui media on line maka pelaku UMKM dapat menjalin komunikasi hubungan yang lebih mudah dengan pelanggan serta dapat selalu memberikan informasi yang terbaru.

\section{KESIMPULAN}


Berdasarkan hasil kegiatan yang telah dilakukan dapat disimpulkan bahwa kegiatan pengabdian kepada masyarakat berupa pelatihan dan pendampingan kepada pelaku UMKM di Perumahan Buana Impian 2 berhasil dengan baik. Hal ini berdasarkan diskusi dengan para peserta usai pelatihan, mereka merasa mendapatkan gambaran mengenai laporan keuangan secara lengkap dan berharap ada pelatihan lebih lanjut sampai mereka benar-benar dapat mempersiapkan laporan keuangan usaha masing-masing secara utuh. Dalam diskusi dengan para peserta, mereka belum memiliki pengetahuan mengenai pembuatan laporan keuangan. Tidak hanya pelatihan tentang membuat laporan keuangan tetapi juga diberikan tentang manajemen pemasaran untuk memasarkan produkproduk yang mereka hasilkan.

\section{SARAN}

Pengabdian kepada masyarakat ini sangat berfaat bagi pelaku UMKM di Perumahan Buana Impian 2 Kelurahan Tembesi. Setelah mengikuti pelatihan dan pendampingan ini diharapkan para pelaku UMKM dapat meningkatkan usaha kearah yang lebih baik. Dalam pelaksanaan pelatihan dan pendampingan ini, masih banyak kekurangannya, diharapkan kedepannya dalam pelaksanaan lebih baik lagi.

\section{UCAPAN TERIMA KASIH}

1. Kepala LPPM Universitas Putera Batam yang telah memfasilitas kegiatan pengabdian kepada Masyarakat.

2. Lurah Tembesi

3. Ketua RT dan Ketua RW 028 Perumahan Buana Impian 2

4. Ketua UMKM Buana Impian 2

5. Peserta Pelatihan UMKM
Prosiding Seminar Nasional Unimus (Volume 1, 2018).

(2) Citra Sukmadilaga, Sudrajat sudrajat, Uswatun Khasanah, Tri Utami Lestari, Meita candra devi, dan Ardian Ardian (2018). Pelatihan Penyusunan Laporan Keuangan Untuk Start UP Company Binaan Digital Lounge (Dilo) PT. Telkom Bandung. Dharmakarya: Jurnal Aplikasi Ipteks untuk Masyarakat. Vol. 7, No. 3, September 2018: 209 - 212

(3) LB. Ruth Florida W. M. Hutabarat (2015). Strategi Pengembangan Usaha Kuliner di Kota Malang Berbasis Ekonomi Kreatif. JESPVol. 7, No 1 Maret 2015

(4) Verniaputri Agusetyaningrum, M. Khalid Mawardi, dan Edriana Pangestuti (2016). Strategi Pengembangan Usaha Kecil Dan Menengah (UKM) Untuk Meningkatkan Citra Kota Malang Sebagai Destinasi Wisata Kuliner (Studi Pada Ukm Berbasis Kuliner Kota Malang) Jurnal Administrasi Bisnis (JAB)|Vol. $38 \quad$ No.2 September 2016.

\section{REFERENSI}

(1) A. Aviv Mahmudi, Wulan Suryandani (2018). Strategi Pengembangan UKM Keripik Tempe Desa Tahunan Kecamatan Sale Kabupaten Rembang. 